\title{
O PODER DO LÓGOS E SUA DIMENSÃO MORAL
}

\section{THE POWER OF LÓGOS AND ITS MORAL DIMENSION}

\author{
Ana Paula Grillo El-Jaick ${ }^{*}$ \\ Laís Lagreca de Carvalho**
}

\section{RESUMO}

Este trabalho tem como objetivo enfatizar a força coercitiva existente na linguagem, a qual vem sendo elucidada desde a Antiguidade com os sofistas, como é possível visualizar com Górgias, mais especificamente no Elogio de Helena. A visão sofística sobre a linguagem pode ser considerada uma visão embrionária daquilo que veio a ser chamado de pragmática, e é possível ver essa relação, por exemplo, nos trabalhos do filósofo britânico John L. Austin, com destaque à sua teoria sobre os Atos de Fala (AUSTIN, 1990 [1955]). O poder do lógos deve ser pensado como algo capaz de mudar o estado de coisas em que uma dada situação se encontra, sendo necessário considerar a dimensão moral de seu uso, conforme Paveau (2015), uma vez que, através dele, mais do que dizemos, fazemos coisas. Nesse sentido, este trabalho parte de uma notícia a partir da qual é possível verificar o poder do discurso e suas consequências, que em alguns casos podem ser negativas. Ademais, mobilizaremos o conceito de "pós-verdade", que vem ganhando espaço e sendo cada vez mais usado, relacionando-o com aquele poder do discurso sofístico e austiniano.

Palavras-chave: moral $_{i}$ pragmática; sofistas.

\section{ABSTRACT}

This work aims to emphasize the coercive force existing in language, which has been elucidated since Antiquity with the Sophists, as it is possible to visualize with Gorgias, more specifically in the Praise of Helena. The sophistical view of language can be considered an embryonic vision of what has come to be called pragmatics, and it is possible to see this relation, for example, in the works of the British philosopher John L. Austin, with emphasis on his theory on the Acts of Speech (AUSTIN, 1990 [1955]). The power of lógos must be thought of as something capable of changing the state of things in which a given situation is found, and it is necessary to consider the moral dimension of its use, according to Paveau (2015), since through it, more than just say, we do things. In this sense, this work starts from a news report from which it is possible to verify the power of discourse and its consequences, which in some cases may be negative. In addition, we will mobilize the concept of "posttruth", which has gained space and been increasingly used, relating it to that sophistical and Austinian power of discourse.

Keywords: moral; pragmatic; sophists.

\footnotetext{
* Universidade Federal de Juiz de Fora, Juiz de Fora (MG), Brasil. anapaulaeljaick@gmail.com.

** Universidade Federal de Juiz de Fora, Juiz de Fora (MG), Brasil. laislagreca@gmail.com.
} 


\section{INTRODUÇÃO}

O título "Mulher morta após boato em rede social é enterrada em Guarujá, SP"1 (Anexo I) atribuído à notícia que apresenta, de forma resumida, os acontecimentos que se sucederam à morte de Fabiane Maria de Jesus, espancada e morta em Guarujá por ter sido confundida com uma suposta sequestradora de crianças, pode nos remeter a questionamentos relacionados a temas muito contemporâneos. Dentre esses temas, recebe destaque a questão da "pós-verdade" e suas implicações morais, já que esse adjetivo diz respeito a circunstâncias em que fatos objetivos têm menos relevância do que crenças sociais. ${ }^{2}$ Ademais, a partir desse mesmo título, podemos levantar discussões referentes à própria linguagem, as quais acontecem em nossa tradição ocidental desde a Grécia antiga, ${ }^{3}$ como podemos ver com os sofistas, que, na Antiguidade, já atribuíam ao lógos um grande poder, um poder mesmo demiúrgico, segundo Helena Martins (2011). Seguindo o pensamento de Martins, autora em quem muito nos basearemos, também relacionaremos tal poder demiúrgico da linguagem flagrado pelos sofistas aos trabalhos de um filósofo contemporâneo, J. L. Austin, que acredita que mais do que dizer o mundo, a linguagem é capaz de criar mundos, isso na medida em que defende que "dizer é fazer" (cf. Austin. 1955).

Nesse sentido, o presente trabalho, visando demonstrar o poder que a linguagem carrega, traça um caminho que, em cada ponto, toca na questão da parte moral que esse poder envolve. Na primeira seção, será apresentado o adjetivo que entrou para o Oxford Dictionaries como a palavra de 2016 que mais despertou interesse aos falantes: "pós-verdade" ${ }^{4}$ A ela serão relacionados os pensamentos dos sofistas, com destaque a Górgias, e o pensamento do filósofo Austin e suas contribuições para os estudos da pragmática - para, então, serem levantadas questões morais em que o discurso se encaixa, seguindo as ideias de Paveau (2015). Na segunda seção, as questões levantadas na seção anterior serão usadas como suporte para a análise

1. A notícia pode ser lida na íntegra no site: $<$ http://g1.globo.com/sp/santos-regiao/noticia/2014/05/ mulher-morta-apos-boato-em-rede-social-e-enterrada-nao-vou-aguentar.html $>$

2. Conforme veremos, essa própria noção já é controversa, pois ela implica uma crença em uma concepção de verdade factual bastante discutível. Se nossa tradição platônico-aristotélica advogará pela estabilidade de uma verdade última transcendental, por outro lado, uma desconfiança cética com relação aos objetos do mundo - e, consequentemente, de sua verdade objetiva - já circulava entre os gregos pelo menos desde Pirro de Élis. Essa questão não se esgota - o que, de certo modo, possibilita a criação de fake news, por exemplo.

3. Muitos autores, como Danilo Marcondes (1997), consideram que um dos primeiros registros de nossa tradição ocidental sobre o tema é o diálogo socrático Crátilo, de Platão.

4. Ainda que possamos empregar o termo "pós-verdade" como um substantivo, o Dicionário Oxford categorizou esse verbete como um adjetivo. 
da notícia sobre a morte de Fabiane. Por fim, serão apresentadas as conclusões do trabalho.

\section{A PÓS-VERDADE E OS SOFISTAS}

De acordo com a Oxford Dictionaries ${ }^{5}$, departamento da Universidade de Oxford responsável pela elaboração de dicionários, a palavra eleita como a palavra do ano de $2016^{6}$ foi "pós-verdade" [post-truth]. A definição da palavra vencedora é a de adjetivo que se relaciona ou denota circunstâncias nas quais fatos objetivos têm menos influência em moldar a opinião pública do que apelos à emoção e a crenças pessoais. Ela foi usada pela primeira vez em 1992 pelo dramaturgo sérvioamericano Steve Tesich e vem sendo empregada com maior frequência há cerca de uma década, tendo havido um aumento significativo em seu uso no ano de 2016. De acordo com as informações veiculadas na página do dicionário na internet, a palavra composta "pós-verdade" traz uma expansão do sentido do prefixo "pós" que, em vez de se referir simplesmente ao tempo após uma situação ou evento específico (como o "pós-guerra", por exemplo), o prefixo unido à palavra "verdade" ganhou um sentido mais próximo ao de "pertencer a uma época em que o conceito especificado (a verdade) se tornou sem importância ou irrelevante". Além disso, o que pode ter colaborado para o uso crescente dessa palavra foi o contexto político das eleições presidências dos Estados Unidos em 2016, pois, por causa disso, ela ganhou espaço na internet através de discussões políticas, contendo comentários que não necessariamente traziam informações verdadeiras, e que nem por isso deixavam de ganhar uma propagação e até mesmo um status de verdade.

Partindo, então, da atualidade da palavra "pós-verdade", podemos nos remeter ao pensamento sofístico (o que mostra igualmente sua anacrônica atualidade), que, por mais que esteja situado em um tempo distante do nosso (uns 26 séculos), faz-se presente e imponente quando pensamos no poder do lógos, no poder do discurso a que aqueles filósofos já apontavam. ${ }^{7}$

5. Informações retiradas do site: <https://en.oxforddictionaries.com/word-of-the-year/word-of-theyear-2016>.

6. A editora de dicionários "Oxford Dictionaires" elege todo ano a palavra que atraiu um grande interesse nos últimos meses.

7. É preciso deixar claro que, quando falamos em "poder do lógos", estamos nos referindo ao pensamento sofístico - que, como se verá mais adiante, dava ao lógos uma espécie de poder criador. Conforme essa perspectiva sofística de linguagem vem sendo resgatada por autores como Barbara Cassin, percebemos que o embate entre os sofistas e Sócrates se dava fundamentalmente na arena da linguagem. Afinal, a ideia platônico/socrática seria a de que seria preciso uma correspondência entre os nomes e as formas dos objetos do real para garantir a estabilidade do significado linguístico 
Helena Martins (2011), ao tratar dos "Três caminhos na filosofia da linguagem", demonstra como, conforme diz o próprio título, três paradigmas atuais sobre o entendimento da linguagem (realismo, mentalismo e pragmatismo) ganham forma bem cedo na história da Filosofia. A autora aponta que as diferentes filosofias da linguagem surgidas na Filosofia respondem a questionamentos relacionados à questão do sentido, que, por sua vez, geravam discussões sobre a linguagem, as quais estavam subordinadas à busca pela verdade. Dentre os três paradigmas mencionados, o pragmatismo se relaciona com as discussões desenvolvidas neste trabalho, na medida em que tem sido associado à filosofia sofística no que tange à perspectiva linguística presente no pensamento desses sábios. A perspectiva de linguagem presente na filosofia sofística demonstra que a linguagem humana é significativa quando "é usada ou vivenciada no fluxo das práticas e costumes de uma comunidade linguística, histórica e culturalmente determinada" (MARTINS, 2011, p. 442), indo além da ideia de significação relacionada à identificação de parcelas do mundo real ou da representação de acontecimentos mentais compartilhados entre falantes e ouvintes.

Para trazer o pensamento sofístico e relacioná-lo com um embrião do que entendemos hoje por pragmatismo, Helena Martins (2011) chama a atenção para o fato de que os sofistas são geralmente associados aos "rivais" dos filósofos dito "socráticos", de modo que para

compreender esse antagonismo supõe, em primeiro lugar, abandonar o estereótipo comumente associado aos sofistas, segundo o qual esses mestres de retórica e oratória que corriam as cidades com seus ensinamentos não passavam de indivíduos venais, destituídos de ética inescrupulosos manipuladores da linguagem e das opiniões, interessados apenas em equipar os seus pupilos com técnicas eficientes para defender seus próprios interesses nas assembleias, onde se decidiam, pelo debate, as leis e os rumos dos acontecimentos civis em geral (Martins, 2011, p. 447).

Essa imagem estereotipada está sendo contraposta com outra que revaloriza a contribuição intelectual dos sofistas, sustentando-se que "foram filósofos e educadores, além de mestres de oratória e retórica, embora esse papel lhes seja negado, por exemplo, por Platão" (Marcondes, 1997, p. 42; ver também Cassin, 1990). Desse modo, é possível compreender que o pensamento linguístico originado

- para que, por exemplo, num silogismo lógico, o nome usado na premissa fosse o mesmo do usado na conclusão. Importante ressaltar que, dessa forma, era preciso que a linguagem funcionasse dessa maneira para que verdades fossem estabelecidas. Isso quer dizer que, para essa tradição platônica, a estabilidade da linguagem é a própria condição de possibilidade do conhecimento. Já os sofistas, pragmáticos avant la lettre, recusavam qualquer explicação metafísica para o significado linguístico. Para eles, o lógos, como "grande soberano", pode estabelecer verdades, criar verdades. 
no mundo grego estava sujeito a debates e a tomadas de posição vinculados à questão da verdade, tendo em vista que, de forma resumida, para Platão e Aristóteles, haveria uma verdade que prevaleceria aos consensos e, para os sofistas, o consenso é que prevaleceria sobre a verdade.

Helena Martins (2011) ressalta a dificuldade em se traçar o que seria o "pensamento sofístico" sobre a linguagem devido aos escassos fragmentos originais que chegaram até os nossos dias. Assim, restam para análise e apreciação apenas os testemunhos de suas ideias reportados pela voz de um dos seus mais provocativos adversários: Platão. Martins (2011) destaca que o legado filosófico que é, com frequência, atribuído aos sofistas é o do relativismo (tese radical da impossibilidade de que verdades universalmente válidas, autônomas com relação às circunstâncias concretas, contingentes e variáveis sejam estabelecidas. Assim, qualquer formulação pode ser verdadeira, impossibilitando a certeza sobre o que se diz). ${ }^{8}$ De acordo com o relativismo, a realidade não poderia ser submetida a uma apreensão final e verdadeira, uma vez que o homem seria a única medida das coisas, o que impediria uma medida única, apriorística, essencial.

Martins (2011) apresenta um fragmento Do não ser, em que o sofista Górgias demonstra que a linguagem não diz o mundo exterior a nós; o que a linguagem diz é tão somente a própria linguagem: "não são pois os seres que nós revelamos àqueles que nos cercam; nós só lhes revelamos um discurso que é diferente das substâncias" (Fragmento B, III, apud MARTINS, 2011). Nesse sentido, é possível perceber que, para Górgias, aquilo que entendemos por "real" é apenas o que se manifesta para nós no discurso, de modo que as coisas ganham existência no uso da linguagem. Portanto, o pensamento sofístico pode ser associado a um posicionamento que vê a existência humana como linguisticamente articulada, colocando a linguagem com uma função decisiva nas experiências humanas no mundo.

Podemos, então, nos questionar sobre o que a linguagem diz, se ela não diz o real. Segundo Martins (2011), nessa perspectiva sofística, a linguagem revela

8. Estamos aqui colocando a questão do relativismo de forma bastante resumida. Essa ideia, afinal de contas, é muito mais complexa e antiga do que estamos aqui sumarizando. Ela circulava já na Grécia antiga e a vemos recorrente em pensamentos de vários filósofos, como Agripa, filósofo contemporâneo de Aristóteles de que pouco se sabe, a não ser isto: que era contemporâneo de Aristóteles - e que, ao contrário deste, era um cético. Segundo Diógenes Laércio em sua obra Vida, doutrinas e sentenças dos filósofos ilustres, Agripa teria sido o autor (ou, ao menos, o compilador) de cinco tropos (ou modos) que levam à suspensão de juízo sobre a possibilidade de fazer asserções em relação ao que quer que seja. São estes seus cinco tropos: do conflito, do regresso ao infinito, da relatividade, da hipótese, e do círculo vicioso (apud SEXTO EMPÍRICO, Hipotiposes pirrônicas, I §164-177). Para Agripa, esses cinco tropos desmascarariam a pretensão dos dogmáticos que se precipitavam em afirmar terem descoberto A Verdade - definitiva, essencial, eterna. 
as próprias opiniões ou impressões dos homens, opiniões que permitem formar consensos, que, por sua vez, responderiam pela estabilidade da linguagem. A linguagem revela sua volatilidade, já que, sob a perspectiva sofística, sua estabilidade não é maior (nem menor) do que a dos consensos presentes nas relações humanas.

Ainda sobre a questão do significado, seguindo a forma sofística de ver a linguagem não seria adequado pensar no sentido como algo fixo, pertencente à expressão em si mesma, mas mais em um "fazer sentido"; isso porque um dos pontos centrais da sofistica é o fato de um mesmo dizer, consideradas as brechas deixadas pela relativa precariedade dos consensos que regulam as práticas humanas, poder significar não apenas mais de uma coisa, mas também significar determinada coisa e seu exato contrário. Com isso, a distinção entre verdade e falsidade é enfraquecida, pois, para essa concepção de linguagem, se não há verdades objetivas nem na própria realidade, tampouco as haverá de forma independente do uso linguístico. A linguagem só passa a ter significado no uso (MARTINS, 2011).

Podemos confirmar o destaque conferido à linguagem com relação à construção de verdades no Elogio de Helena, de Górgias. Nesse texto, Górgias apresenta quatro possíveis justificativas que isentariam Helena da culpa por ter fugido de Troia com Páris, mas, mais do que a apresentação dessas justificativas, nos chama a atenção especificamente uma delas: aquela que coloca Helena como tendo sido persuadida pelo discurso.

O discurso, na perspectiva sofística, é capaz de exercer diversas ações no mundo, como podemos ver no seguinte trecho, com Górgias nos falando:

\footnotetext{
Mas se aquele que a persuadiu, que construiu uma ilusão em sua alma, foi o discurso, também não será difícil defendê-la contra esta acusação, e destruir a inculpação da seguinte forma: o discurso é um grande soberano que, por meio do menor e do mais inaparente dos corpos, realiza os atos mais divinos, pois ele tem o poder de dar fim ao medo, afastar a dor, produzir alegria, aumentar a piedade. [...] Aquele que persuade, na medida em que constrange, comete então uma injustiça, mas quanto à persuadida, na medida em que foi constrangida pelo discurso, é sem razão que dela se ouvem imprecações [...] (Górgias, Elogio de Helena).
}

Através dessa passagem, fica nítido o status atribuído ao discurso pelo sofista Górgias, tendo em vista que ele é qualificado como "um grande soberano", por meio do qual atos de diversas naturezas podem ser executados. Desse modo, a inculpação que recai sobre Helena não se sustenta, pois não haveria como ela se defender desse poder atribuído ao lógos.

Com relação ainda a esse poder do discurso, Górgias faz uma analogia em que compara o poder exercido pelo discurso sobre a alma com o poder que as drogas exercem sobre os corpos: 
Pois existe uma mesma relação entre o poder do discurso e disposição da alma, dispositivo das drogas e natureza dos corpos: assim como tal droga faz sair do corpo um tal humor, e que umas fazem cessar a doença, outras a vida, assim também, dentre os discursos, alguns afligem, outros encantam, fazem medo, inflamam os ouvintes, e alguns, por efeito de alguma má persuasão, drogam a alma e a enfeitiçam (Górgias, Elogio de Helena).

Com essa analogia, Górgias toca no ponto mais interessante sobre o que a linguagem representa em uma sociedade, pois, assim como ela pode interferir positivamente nas almas, como muitos remédios fazem com os corpos, pode também funcionar como um veneno, como algo capaz de enfeitiçar e provocar reações indesejáveis à alma, as quais se refletem na vida das pessoas, como no caso apresentado pela notícia trazida neste trabalho.

Com tudo e por tudo o que foi dito sobre os sofistas até aqui, pensando na mudança de paradigma com relação à verdade proposta por eles, é importante, conforme destaca El-Jaick (2016), reconhecer que,

Ao contrário de simplesmente identificar os sofistas contemporaneamente com políticos ou publicitários de forma pejorativa, podemos vislumbrar ali um sofisticado pensamento filosófico - baseado em certa visão (radicalmente pragmática) de linguagem (EL-JAICK, 2016).

Esse mesmo ponto de vista, em que à linguagem é atribuída uma função muito maior do que simplesmente dizer o mundo, posto que ela cria mundos, pode ser encontrado nos trabalhos do filósofo da linguagem John Langshaw Austin, conhecido pela criação da Teoria dos Atos de Fala e um dos mais renomados representantes dos estudos pragmáticos da linguagem. Desse modo, a semelhança encontrada entre a perspectiva de linguagem austiana e a perspectiva de linguagem sofística nos permite dizer que haveria nesta última uma espécie de embrião de uma visão radicalmente pragmática de linguagem.

\section{O PODER DA LINGUAGEM EM AUSTIN}

O projeto filosófico da teoria dos atos de fala de Austin, segundo Danilo Marcondes ${ }^{9}$, insere-se na tradição britânica da filosofia analítica, inaugurada por G. R. Moore, B. Russell e L. Wittgenstein nas primeiras décadas do século XX. Essa filosofia surge como uma dupla reação às correntes de pensamento filosófico que predominavam na Grã-Bretanha ao final do século XIX: o idealismo absoluto de F. H. Bradley e T. H. Green e o empirismo influenciado por J.S. Mill.

9. O texto de Danilo Marcondes que serviu de base para esta parte do trabalho é a Apresentação da edição brasileira de Quando dizer é fazer (1990), traduzida por ele. 
Em seu início, a filosofia analítica, com Moore e Russell, partia de uma concepção realista que buscava compreender os elementos centrais de nossa experiência através da análise da forma lógica das sentenças que transmitem nosso conhecimento, crenças e opiniões sobre o real, e por meio das quais a nossa experiência é articulada. Nesse sentido, a antiga problemática da consciência dá lugar à problemática da linguagem, já que os filósofos não mais buscavam a resposta na consciência, mas na linguagem.

Aprendemos com Marcondes (1990) que, dentro dessa tarefa filosófica pela busca do significado, há duas correntes: uma que procura estabelecer a forma lógica e os elementos constitutivos da linguagem, e outra que, por meio da reinvestigação de problemas filosóficos tradicionais em teoria do conhecimento, teoria da percepção, ética etc., busca analisar linguisticamente os conceitos centrais dessas áreas, relacionando-os à linguagem ordinária. Ademais, Marcondes destaca que essas duas formas de analisar a linguagem dividiram-se no que se pode chamar, em um sentido estrito, de filosofia da linguagem, que se preocupa com a natureza e a estrutura da linguagem, examinando noções como termo e proposição, sentido e referência, nomes próprios e predicativos etc., e de filosofia da linguagem ordinária, em que Austin é considerado um dos principais nomes.

Os trabalhos desenvolvidos por Austin são constituídos por discussões sobre determinados problemas centrais da tradição filosófica, como responsabilidade e ação, percepção e conhecimento etc. Essas discussões acontecem por meio do método da análise da linguagem ordinária. Segundo Austin, tal análise seria capaz de clarificar e desmitificar os problemas tradicionais filosóficos, colocando-os em um plano menos abstrato e, assim, permitindo uma análise e uma compressão desses problemas sem se recorrer a pressupostos metafísicos - que acabariam gerando novos problemas e novas discussões.

Marcondes destaca que, nessa perspectiva de análise linguística adotada por Austin, ao analisarmos a linguagem, o objetivo não é o de simplesmente analisá-la como uma estrutura, ou por ela mesma, mas sim investigá-la levando em consideração o contexto social e cultural no qual ela acontece, as práticas sociais em que está envolvida, os paradigmas e valores a que está submetida, a "racionalidade" da comunidade em que está imersa - ou seja, é preciso considerar os elementos que são indissociáveis da linguagem, uma vez que ela ganha sentido no uso. Com isso, a partir desse modo de enxergar a linguagem, esta passa a ser vista como ação. $\mathrm{O}$ ato de fala (r) estabelece um contrato, um compromisso entre os falantes, de modo que, com a linguagem, somos capazes de agir sobre o real (não simplesmente de dizêlo). Assim, a análise das sentenças com foco na verdade passa a uma análise com 
foco na eficácia do ato de fala, com a sua "felicidade", considerando as condições necessárias para seu sucesso - e também a dimensão moral do compromisso assumido durante a interação comunicativa.

A grande contribuição de Austin para a filosofia da linguagem, então, é a de considerar a linguagem como uma forma de ação, e não como um mero instrumento para nomear as coisas do mundo. Essa concepção de linguagem está presente no pensamento sofístico, a qual também representava, na Antiguidade, uma contraposição a uma visão essencialista voltada para a preocupação com o acesso a uma verdade transcendental. Portanto, para se chegar ao significado da expressão linguística, não basta analisá-la, simplesmente, com base nos elementos internos que a constituem; antes, é preciso considerar o contexto em que ocorre, as convenções às quais se submete e as intenções dos participantes envolvidos na interação. ${ }^{10}$

Por tudo o que foi dito, não é difícil perceber a relevância dos estudos de Austin para o desenvolvimento da pragmática nos estudos linguísticos, na medida em que ele colocou em evidência as diversas funções que os enunciados podem desempenhar na interação verbal. Baseando-se no princípio de que "dizer é fazer", Austin apresenta os atos performativos e constativos, os quais, em um primeiro momento, são tratados diferentemente, sendo o primeiro relacionado aos enunciados que possuem um caráter contratual, criador de um novo estado de coisas, e o segundo relacionado aos enunciados que são passíveis de serem analisado segundo critérios de verdade ou falsidade. No entanto, posteriormente, o filósofo chega à conclusão de que as fronteiras que separam os atos performativos dos constativos são muito tênues, de modo a serem facilmente desfeitas; isso porque as declarações (os modelos de enunciados constativos) são também passíveis de serem analisadas de acordo com as condições de felicidade estipuladas para os atos performativos (GOUVEIA, 1996), as quais foram apresentadas por Austin na sua segunda conferência ${ }^{11}$ :

(A.I) Deve existir um procedimento convencionalmente aceito, que apresente um determinado efeito convencional e que inclua o proferimento de certas palavras, por certas pessoas, e em certas circunstâncias; além disso que

(A.2) as pessoas e circunstâncias particulares, em cada caso, devem ser adequadas ao procedimento específico invocado.

10. Quanto às intenções dos participantes, conforme repetiremos logo adiante, diz Austin: "Os participantes devem ter a intenção de se conduzirem de maneira adequada e, além disso, devem realmente conduzir-se dessa maneira subsequentemente" (1990, p. 31).

11. O livro já citado Quando Dizer é Fazer se constitui de conferências de Austin, proferidas na Universidade de Harvard, nos Estados Unidos, no ano de 1955. 
(B. I) O procedimento tem de ser executado, por todos os participantes, de modo correto e (B. 2) completo.

(Г.1) Nos casos em que, como ocorre com frequência, o procedimento visa as pessoas com seus pensamentos e sentimentos, ou visa a instauração de uma conduta correspondente por parte de alguns dos participantes devem ter a intenção de se conduzirem de maneira adequada, além disso,

(Г.2) devem realmente conduzir-se dessa maneira subsequentemente. (Austin, 1990, p. 31).

O estabelecimento das condições necessárias para a realização de atos de fala felizes (como já dissemos, a felicidade do ato substitui a noção de aceitabilidade de uma proposição de acordo com seu valor de verdade), ponto de partida de Austin para desenvolver contrariamente a doutrina das infelicidades, busca mostrar que as falhas concernentes à realização dos atos de fala podem ser de natureza variada. De acordo com Austin, ao ser transgredida uma dessas seis regras, o ato de fala será malogrado. No entanto, há diferenças consideráveis sobre a forma como um ato pode ser malogrado. Ao grafar as quatro primeiras regras dos Atos de Fala com letras latinas e as duas últimas com uma letra grega, Austin chama a atenção para a diferença entre as quatro primeiras regras e as duas últimas: quando as regras do tipo A ou B são violadas, o ato que estava a ser executado não foi realizado com êxito, não sendo, por isso, concretizado; quando, por outro lado, são violadas as regras $\Gamma$, o ato é concretizado, embora tenha sido realizado através da falta de sinceridade. Assim, Austin denomina como "desacertos" os atos malogrados do tipo A.1 - B.2, em contraposição aos atos $\Gamma$, que, quando malogrados, são denominados "abusos", em que há a concretização da ação, ainda que ferindo os princípios de sinceridade.

As condições necessárias para atos de fala felizes estipuladas por Austin representam uma tentativa de se criar regras que permitam analisar o aparente "caos": a linguagem enquanto uso, aquilo que por muito tempo fora deixado de lado nos estudos linguísticos, em detrimento de análises mais racionais e lógicas. Pensando nos objetivos deste trabalho, voltamo-nos para as regras estipuladas por Austin. Podemos pensar que as regras do tipo $\Gamma$, uma vez que a linguagem é ação, representam um problema de natureza moral, ao qual o uso da linguagem, inscrito em relações reais do mundo, está sujeito.

\section{A FACE MORAL DA LINGUAGEM}

Marie-Anne Paveau (2015) apresenta o título do verbete "Reprovação e aprovação", subintitulado: "Os atos de fala com alcance moral" de S. Laugier, propondo uma relação entre linguagem e moral, e mostra como a virada linguística 
na filosofia, com destaque aos trabalhos de Austin, apaga um pouco a distinção entre linguagem e ação. Segundo Laugier (apud PAVEAU, 2015), antes da virada linguística na filosofia, as análises eram feitas apenas quanto à dimensão lógica da linguagem, extraindo dela qualquer vestígio da dimensão moral. Somente com os estudos de Austin é que o critério de verdade sofreu de fato uma modificação, isto é, com a teoria dos atos de fala, na qual o critério de verdadeiro ou falso cedeu lugar ao critério de ato de fala feliz ou infeliz, deslocando a norma da verdade em direção a outra coisa relacionada à satisfação do ato. Nesse sentido,

\begin{abstract}
a aprovação e a reprovação já não são então atos de fala "com alcance moral", entre outros: representam e resumem a dimensão moral da linguagem, o fato de que toda atribuição de verdade ou falsidade é de alguma maneira uma tomada de posição moral. O próprio uso da linguagem (o fato de que ela sempre se dirige a alguém, em dado contexto) baseia-se na reprovação (rejeição daquilo que digo, como inadequado) e na aprovação (aceitação daquilo que digo, como algo que satisfaz às normas da comunidade Linguística) (Laugier, 2001, pp. 194-195 apud PAVEAU, 2015, p. 60).
\end{abstract}

Para Paveau, a aprovação e a reprovação de um discurso refletem a dimensão moral que ele carrega, pois pensamentos do tipo "fica bem dizer isso" ou "não é adequado dizer isso" estão subordinados ao uso da linguagem relacionado às instâncias que lhe permitem fazer sentido (os participantes, os propósitos, o tempo do discurso, o local do discurso, o veículo etc.). (2015, p. 60)

Paveau (2015) também se debruça sobre a questão da mentira e sua relação com a enunciação e a intenção. S. Laugier, em seu verbete sobre a "mentira", coloca-a como um enunciado que, por sua natureza, não seria atingido pela moral, pertencendo à alçada da enunciação; contudo, sendo o enunciado um ato, conforme Austin o coloca, a mentira seria um enunciado falso, dotado de intenção e, por essa razão, estaria situada no limite entre linguagem e moral. Ainda segundo Paveau, Wittgenstein vê a mentira como um dos possíveis jogos de linguagem, enquanto Austin a vê como um ato de fala, numa perspectiva mais moral, enxergando-a como um abuso de linguagem passível de sansão.

Nesse sentido, Paveau (2015) propõe uma ética discursiva no que diz respeito a uma linguística simétrica, em que a mentira e, de modo geral, a dimensão moral dos enunciados poderiam ser linguisticamente detectáveis através da adoção de uma concepção que integrasse a atividade linguageira, considerando os agentes, suas disposições e suas virtudes, as relações entre si, a visada de uma boa comunicação e o estado de coisas. Com isso, passa a ser possível incluir, nas análises linguísticas, aquilo que foi bastante rejeitado pela tradição estruturalista: as intenções do agente (PAVEAU, 2015). 
Com base no que foi exposto, é possível perceber que a perspectiva de linguagem presente no pensamento sofístico, a qual coloca o lógos, o discurso, em uma posição de destaque - afinal, "o discurso é um grande soberano" -, tem reflexos na concepção de linguagem de Austin, já que, uma vez mais, ao discurso é atribuído o poder de fazer coisas, de criar mundos. Desse modo, ao pensarmos na práxis linguística e em suas implicações, quando à linguagem é claramente conferido um poder criador de realidades, podemos pensar nas implicações morais a que o uso de nossos "dizeres" está submetido.

Por fim, voltamos à questão da "pós-verdade", que está diretamente ligada à prática discursiva e associada ao poder do lógos, tendo em vista que aquilo que o discurso cria, assim como os efeitos das drogas, pode ter bons ou maus resultados. Ademais, mais uma vez a face moral dos nossos atos de fala se mostra, pois por trás de algo classificado como "pós-verdade" há toda uma relação intencional e, consequentemente, moral.

\section{O PODER DO LÓGOS E SUAS CONSEQUÊNCIAS}

Com o advento tecnológico e a facilidade ao acesso à internet, o número de pessoas que, atualmente, possui redes sociais, como Facebook, WhatsApp, cresce cada vez mais. Aqueles que usam alguma dessas redes sociais conseguem pensar, facilmente, em exemplos de divulgação e propagação de notícias, estudos científicos, alertas de toda espécie (vacinas que fazem mal, alimentos contaminados, copos de água ao amanhecer para se evitar câncer etc.) que não possuem uma real relação, um comprometimento com acontecimentos reais. Algo nesse sentido, mas obviamente muito mais grave, fez com que Fabiane Maria de Jesus fosse espancada até a morte em Guarujá, no litoral de São Paulo: uma página no Facebook divulgou um retrato falado de uma mulher suspeita de sequestrar crianças no litoral de São Paulo e várias pessoas pensaram ser a Fabiane. Esse acontecimento, assim como aquelas mensagens "mais inocentes" que nos chegam por grupos do WhatsApp diariamente, as quais também podem gerar mudanças no mundo, como pessoas que deixam de tomar um medicamento que, segundo as informações que chegaram até elas, está fazendo mal à saúde, ganham forma e passam ao status de "verdadeiros" por meio daquilo que articula nossa existência: a linguagem.

Como apresentado anteriormente neste trabalho, os sofistas já demonstravam que a função da linguagem estava além de descrever as coisas do mundo, de dizer o reali para eles, a linguagem cria o real. Aproximativamente, essa mesma visão da 
linguagem, como vimos, é encontrada em Austin, que, acreditando que linguagem é uma forma de ação, estipulou condições para que os atos de fala fossem felizes. É possível, então, relacionarmos essa perspectiva linguística que vê o discurso como um criador de mundos com o que aconteceu no caso da morte de Fabiane, vinculando, assim, o poder do lógos com sua contraparte moral.

Ao pensarmos que esse retrato falado com as informações da possível sequestradora de crianças foi veiculado em uma página voltada para a população do Guarujá, podemos colocar em questão a sua responsabilidade ao fornecer qualquer informação que seja, pois pode exercer influência sobre aqueles que consomem suas informações. Podemos pensar que, considerando a informação fornecida pela página da internet como um ato de fala, -de fato, ele não teria atendido às regras do tipo $\Gamma$, pois não houve, por parte daqueles que veicularam a informação, um comprometimento, relacionado à intenção que os participantes devem ter de se conduzirem de maneira adequada. Dizer mentiras ou dizer algo sobre o que não se tem conhecimento diz respeito aos dois últimos critérios estipulados por Austin, bem como exige que nos posicionemos em relação à dimensão moral da linguagem, pois, se "dizer é fazer", é preciso que se reconheçam as consequências desse poder demiúrgico da linguagem. Com a divulgação dessas informações nessa página da rede social, as pessoas levaram à frente as informações da possível sequestradora de crianças e as relacionaram com Fabiane, que, por sua vez, não teve nem a chance de se defender - não por não querer ou negar o poder do discurso, mas por não ter tido tempo para isso.

Esse acontecimento desumano é mencionado neste trabalho visando ao propósito de se confirmar a leitura dos sofistas como pensadores que já enxergavam o valor do lógos, bem como relacionar o pensamento sofístico sobre a linguagem ao ponto de vista austiniano, que também desloca da linguagem a mera função de dizer as coisas do mundo. Reconhecendo, assim, que o poder do lógos não é uma novidade para a sociedade, é preciso lidar com isso e pensar que, como algo poderoso, o discurso pode fazer coisas maravilhosas - mas, por outro lado, pode gerar muito sofrimento. Nesse sentido, pensar nas intenções dos falantes, por mais que seja um caminho obscuro, é um caminho necessário, porque a linguagem, pensada como forma de ação, tal como ela é, não pode ser dissociada da sua dimensão moral. ${ }^{12}$

12. Devemos lembrar que essa discussão, como acontece nos Estudos da Linguagem, pode ser discutida a partir de vários paradigmas linguísticos. Nosso caminho, aqui, seguiu as pistas da intencionalidade em Austin. Contudo, há diversas possibilidades outras de análise. Por exemplo, Paveau (2015, p.98) cita pelo menos Sophie Moirand como uma analista do discurso que esboçou uma "moral da linguagem" chamando de "ética da responsabilidade em linguagem" o fato de que sujeitos que ocupam certos cargos em determinada sociedade devem ser responsáveis pelos efeitos de seus atos de fala. 
Por fim, podemos encerrar essa confirmação do poder do lógos por aquilo que deu início a este trabalho, a palavra "pós-verdade", acionando, mais uma vez, a dimensão moral da linguagem, porque o conceito de "pós-verdade" abriga a possibilidade de que algo que não corresponde a acontecimentos do mundo possa valer mais do que o que aconteceu, ou faz com que deixe de ser necessário buscar aquilo que "é". Sem esse tipo de preocupação moral, são levados adiante discursos falaciosos que passam a ser, que recebem status de verdade. Essa possibilidade de existirem "pós-verdades" está diretamente ligada à linguagem e, na nossa sociedade, é potencializada pela propagação, quase que imediata, das informações, de modo que, muitas vezes, o conteúdo do que se veicula vale menos do que a quantidade das "visualizações" recebidas. E, conforme já salientamos, nessa "correria" de se criar mundos sem a preocupação com as consequências do uso desse poder da linguagem, este mundo acaba por se transformar, para o bem ou para o mal.

Portanto, assim como é preciso que, para se usar uma ferramenta poderosa, as pessoas aprendam a operá-la e conheçam as consequências que seu uso pode gerar, é preciso que o poder do discurso seja reconhecido como tão belo como pode ser, mas também como possivelmente muito traiçoeiro, uma vez que ele envolve sentimentos e crenças dos envolvidos e pode gerar uma reação em cadeia capaz até mesmo de tirar a vida de alguém, como vimos no caso da Fabiane. Além disso, é importante que o poder do discurso seja pensado em relação à sua rápida propagação nas redes sociais, para que haja uma conscientização do uso dessas ferramentas, que são indissociáveis da linguagem.

\section{CONCLUSÃO}

Pela análise de um acontecimento brutal, foram levantadas questões como a existência de "pós-verdades" e o poder do discurso, traçando um percurso de pensamento sobre a linguagem que vem desde os gregos antigos, mais exatamente os sofistas, até se chegar a seu reflexo na contemporaneidade com Austin. Desse modo, foi possível perceber que o poder do lógos representa uma questão antiga nos debates sobre a construção do sentido.

A proporção que a divulgação de determinada informação nas redes sociais pode tomar deve estar sujeita a penalidades legais rígidas, pois não há um controle sobre como que aquilo que é proferido, por meio do discurso, pode influenciar e agir sobre a vida dos que recebem a informação. Para as pessoas que, ao lerem a notícia sobre a suposta sequestradora de crianças, relacionaram a mulher da 
foto com Fabiane e levaram essa informação adiante, o mundo passou a ser outro: mudou-se o estado de coisas - e, de forma trágica, uma vida foi sacrificada.

A instância moral do discurso pôde ser percebida através da exposição da notícia relacionada à divulgação da informação sobre a possível sequestradora, ressaltando o apontamento de Laugier de que "toda atribuição de verdade ou falsidade é de alguma maneira uma tomada de posição moral." (Laugier, 2001, p. 194-195 apud PAVEAU, 2015, p. 60). Além da questão da aprovação e da reprovação, foi possível pensar na questão da mentira, levantada por Paveau (2015), e também na questão da intenção, que é colocada em destaque por Austin (1990), quando este estabelece as condições necessárias para atos de fala felizes - que foram retomadas por Paveau, na medida em que ela propõe uma concepção de uma ética discursiva em uma linguística simétrica, em que a mentira e a dimensão moral dos enunciados possam ser linguisticamente detectáveis.

Ao pensarmos na "pós-verdade" e em sua grande repercussão no ano de 2016 voltamos à preocupação sobre o poder do discurso e suas consequências. Nesse sentido, mais uma vez é preciso estarmos atentos ao poder do "todo poderoso": 0 lógos, com sua implicação moral.

Sendo assim, a analogia gorgiana que compara o poder do lógos ao poder das drogas é feliz em demonstrar a importância de se pensar a dimensão moral daquilo que, segundo Austin, é nosso penhor: a palavra, o discurso, o lógos. Portanto, considerando a sociedade atual e a rapidez com que informações são trocadas e chegam à vida das pessoas, talvez, mais do que nunca, seja necessário reconhecer o poder do discurso e refletir sobre suas implicações morais.

\section{$\overline{\text { REFERÊNCIAS }}$}

AUSTIN, J. L. (1955) Quando dizer éfazer. Trad. de Danilo Marcondes de Souza Filho. Porto Alegre: Artes Médicas, 1990.

CASSIN, B. (1995) O efeito sofístico: sofística, filosofia, retórica, literatura. Tradução de Ana Lúcia de Oliveira; Maria Cristina Franco Ferraz; Paulo Pinheiro. São Paulo: Ed. 34, 2005.

DIÓGENES LAÉRCIO. (1965a) Vie, doctrines et sentences des pbilosophes illustres. Tome I. Traduction, notice et notes par Robert Genaille. Paris: GF Flammarion.

DIÓGENES LAÉRCIO. (1965b) Vie, doctrines et sentences des pbilosophes illustres. Tome II. Traduction, notice et notes par Robert Genaille. Paris: GF Flammarion. 
EL-JAICK, A. P. (2016) O discurso é um grande soberano: o poder da linguagem e um elogio aos sofistas. É: Revista Ética e Filosofia Política. v. II, nº XIX, p. 39-58.

GÓRGIAS. Elogio de Helena. In: CASSIN, B. (1995) O efeito sofístico: sofística, filosofia, retórica, literatura. Tradução de Ana Lúcia de Oliveira, Maria Cristina Franco Ferraz e Paulo Pinheiro. São Paulo: Ed. 34, 2005.

GOUVEIA, C. A. M. (1996). Pragmática. In: HUB, I. F. et al. Introdução à Linguística Geral e Portuguesa. Lisboa: Caminho, 1996. p. 383-419.

KERFERD, G. B. (2003). O movimento sofista. Trad. Margarida Oliva, Edições Loyola, São Paulo.

MARCONDES, D. (1990). Apresentação. In: AUSTIN, J L. (1955) Quando dizer é fazer. Trad. de Danilo Marcondes de Souza Filho. Porto Alegre: Artes Médicas.

MARCONDES, D. (2017) Iniciação à História da Filosofia Dos Pré-Socráticos a Wittgenstein. $17^{\mathrm{a}}$ edição. Rio de Janeiro: Zahar, 2017.

MARTINS, H. (2011). Três caminhos na filosofia da linguagem. In: MUSSALIM, F.; BENTES, A. C. (Org.). Introdução à linguística: fundamentos epistemológicos, volume 3.5. ed. São Paulo: Cortez.

Notícia G1. (2017). Disponível em: <http://g1.globo.com/sp/santos-regiao/ noticia/2014/05/mulher-morta-apos-boato-em-rede-social-e-enterrada-nao-vouaguentar.html>. Acesso em: 17/07/2017.

OXFORD DICTIONARIES. (2017). Disponível em: < https://en.oxforddictionaries.com/ word-of-the-year/word-of-the-year-2016>. Acesso em: 17/07/2017.

PAVEAU, M. (2015). A. Linguagem e moral: uma ética das virtudes discursivas. Trad.: Ivone Benedetti. Campinas, SP: Editora da Unicamp.

SEXTUS EMPIRICUS. (1994). Outlines of Scepticism. Translated by J. Annas e J. Barnes. Cambridge: Cambridge University Press.

SEXTUS EMPIRICUS. (1990) Outlines of Pyrrbonism. Translated by R. G. Bury. Buffalo, New York: Prometheus Books. 


\section{ANEXO I}

\section{6/05/2014 11h03 - Atualizado em 06/05/2014 13h17 \\ Mulher morta após boato em rede social é enterrada em Guarujá, SP}

Mulher foi morta após página postar boato sobre sequestro e bruxaria. Novo vídeo, divulgado nesta terça, mostra mulher sendo interrogada. Anna Gabriela Ribeiro

Do G1 Santos

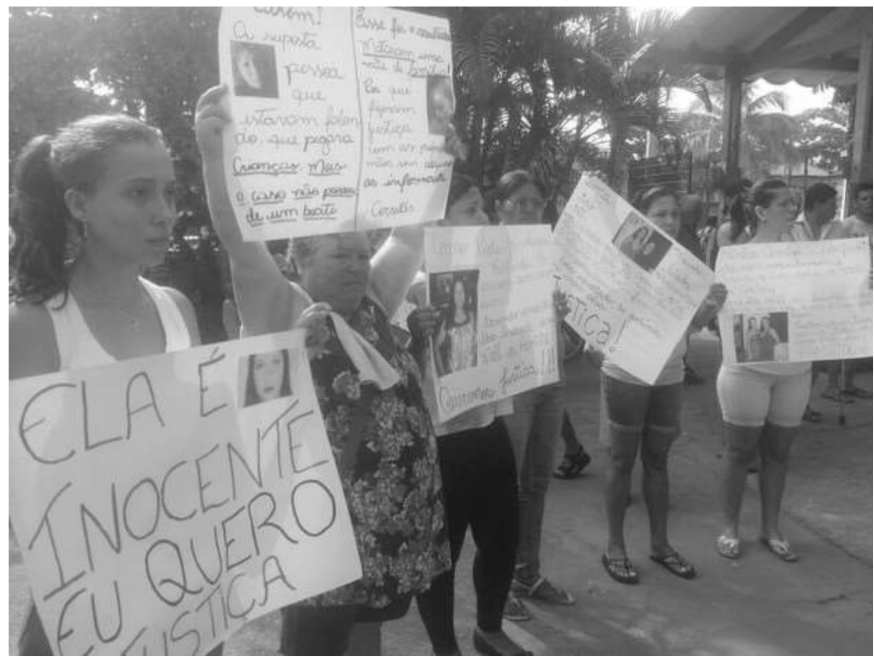

Familiares estenderam faixas em protesto por morte de mulher espancada (Foto: Anna Gabriela Ribeiro / G1)

Centenas de pessoas acompanharam, na manhã desta terça-feira (6), o enterro de Fabiane Maria de Jesus, que foi espancada e morta no último sábado (3) em Guarujá, no litoral de São Paulo, ao ser confundida com uma suposta sequestradora de crianças que praticava rituais de magia negra. A cerimônia reuniu familiares e amigos que não se conformam com a crueldade do crime.

O enterro foi realizado no cemitério Jardim da Paz, no bairro Morrinhos, onde a vítima morava e foi morta. 0 marido, Jaílson Alves das Neves, comentou o caso e diz não sentir ódio dos suspeitos. "Vou chorar. Não vou aguentar. Para mim a ficha não caiu. Apesar da brutalidade, não guardo ódio, não guardo esse sentimento ruim no coração. Espero que não aconteça com mais famílias. Essas pessoas que agrediram ela e as que assistiram não tiveram a coragem de salvar uma pessoa inocente, não deram nem tempo de defesa para minha esposa. Quero que eles reflitam e que isso não aconteça nunca com a família deles", explica. 
O marido espera que os envolvidos sejam punidos. "Que prendam os acusados. Que esse site que postou essa mentira não faça mais essas coisas. Minha filha não teve condições de vir ao enterro. Ela está abalada e quer lembrar apenas do sorriso da mãe", comenta.

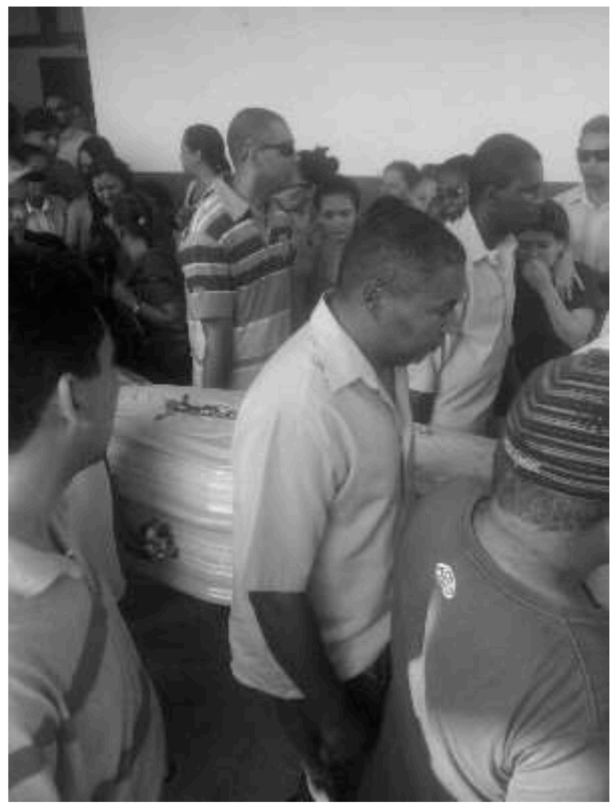

Familiares e amigos carregaram caixão de mulher espancada (Foto: Anna Gabriela Ribeiro / G1)

Um novo vídeo sobre o caso foi divulgado na manhã desta terça-feira (6). Nas imagens, registradas por um cinegrafista amador, a dona de casa aparece tentando pronunciar algumas palavras, na tentativa de impedir que as agressões continuem. Um homem aparece interrogando Fabiane no vídeo. "Nós temos conhecimentos desse vídeo, que foi levado para o delegado, e está anexado nas investigações. Não conseguimos identificar o que ela fala, porque a Fabiane estava muito ferida. Foi uma barbaridade o que aconteceu", diz o advogado da família da vítima, Airton Sinto.

\section{Internautas revoltados com página}

0 administrador da página do Facebook responsável por postar o retrato falado de uma mulher suspeita de sequestrar crianças no litoral de São Paulo será ouvido nesta terça-feira (6) pela Polícia Civil. Após a publicação da foto na página 'Guarujá Alerta', alguns moradores de uma comunidade do município agrediram a dona de casa. Dezenas de usuários da rede social 
criticaram duramente o administrador da página e um deles chegou a dizer que a página seria tão culpada quanto os agressores.

Em uma postagem feita no fim da tarde desta segunda-feira, o dono da página afirma que está colaborando com as investigações e que não irá se pronunciar a respeito do caso para não atrapalhar o trabalho da polícia. Em alguns comentários, os usuários condenaram a publicação do retrato falado, mesmo sabendo que se tratava apenas de um boato.

De acordo com informações do delegado Luiz Ricardo Lara, que está à frente do caso, ainda é cedo para apontar a responsabilidade do administrador da página Guarujá Alerta. "Caso, durante a instrução do inquérito policial, seja vislumbrado que, de alguma forma, ele colaborou com o crime, na medida em que propalou esses boatos, enfim, que praticou uma infração penal, ele será responsabilizado por aquele ato", afirma.

\section{Advogado}

0 advogado ressalta que a polícia continua investigando o crime, mas que o seu próximo passo será pedir a prisão temporária do administrador da página 'Guarujá Alerta'. Para Airton, algumas pessoas teriam visto, nesta página do Facebook, o retrato falado de uma mulher que estaria sequestrando crianças para rituais de magia negra em Guarujá e pensaram que se tratava de Fabiane. "Parece-me que hoje o administrador do site vai depor na delegacia. Mas, independentemente do que vai ser dito por ele para a polícia, eu vou pedir a sua prisão temporária", afirma.

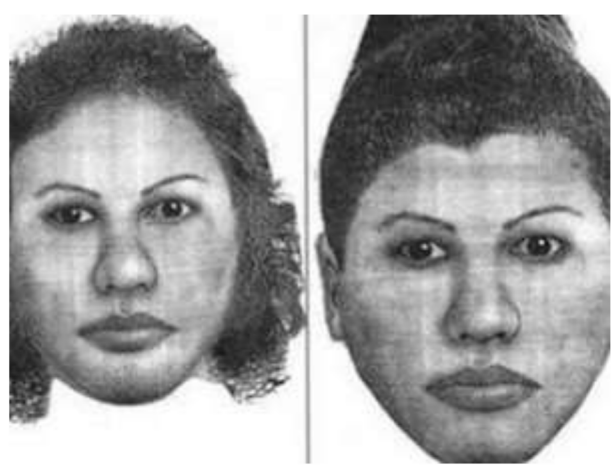

Retrato falado na internet teria gerado agressões contra Fabiane (Foto: Reprodução)

\section{Confusão}

o retrato falado atribuído a Fabiane Maria de Jesus, linchada por moradores do Guarujá (SP) após boatos na internet, havia sido feito por policiais da 21a DP (Bonsucesso), em agosto de 2012. Na ocasião, uma mulher foi acusada de tentar roubar um bebê do colo da mãe em uma 
rua de Ramos, na Zona Norte do Rio.

Imagens de câmeras de segurança divulgadas na época mostraram a mãe, Daniela Mendes, passando com a filha de 15 dias no colo e sendo seguida pela suspeita. A vítima estava levando o bebê para fazer o teste do pezinho em um posto de saúde. Ao sair da unidade, foi surpreendida pela mulher.

Fonte: <http://g1.globo.com/sp/santos-regiao/noticia/2014/05/mulher-morta-apos-boato-em-rede-social-eenterrada-nao-vou-aguentar.html>. Acesso em: 17/07/2017.

Recebido: 21/01/2018

Aceito: 09/07/2018 